\title{
コロンブス以前に旧世界にあったトウモロコシ——回想
}

内林 政夫

\section{The Presence of Pre-Columbian Maize in the Old World-An Overview}

\author{
Masao UCHIBAYASHI \\ Takeda Science Foundation, Juso-honmachi, Yodogawa-ku, Osaka 532-8686, Japan
}

(Received February 15, 2006; Accepted March 23, 2006)

\begin{abstract}
An overview is presented on the reports available so far on pre-Columbian maize covering the regions of India, Mideast, Africa and Iberia. Frequent observations of maize recorded in the past on the East and the West Coast of Africa and at the ports in the Mideast show that maize was one of the staples of the natives well before 1492. It is also evident that maize in the West Africa was disseminated to Iberia and Lombardy in the pre-Columbian time. An earlier contact between the Old and the New World is strongly suggested.
\end{abstract}

Key words_ pre-Columbian; maize; China; India

\section{1. 導入}

トウモロコシはコロンブス一行が新大陸から 1492 年以降にヨーロッパに持ち帰り，それが世界 各地に速やかに伝播していったという図式が，今日 一般に受け入れられている。筆者は前報1)で，コ ロンブス以前にトウモロコシが中国に存在したとい う論考を紹介した．そして，中国への到来のルート の1つとしてインドを示唆した. インドに現存する 13 世紀の寺院にトウモロコシとみられる彫刻があ ると報告されているとしたが，筆者の実地検分を経 ていないのでその追求は控えた.

本報では，過去に発表された多数の研究・調査報 告を概観し， ${ }^{2)}$ コロンブス以前にトウモロコシが各 地に存在したことを回想する.

\section{2. インド}

アメリカのジョハンセンは 1988 年「12 世紀のイ ンドのトウモロコシ」と題して報告した. ${ }^{3)}$ インド 南部内陸部の町バンガロールの南西のマイソールの 近くで，ホイサラ王朝（11-13 世紀）の 12-13 世紀 に建てられた寺院の壁面に男女神の彫刻があり，そ れらの神々がトウモロコシの雌穂，穀実を表わすも のを手にしている—という報告を神像の写真を添

武田科学振興財団（干532-8686 大阪市淀川区十三本町 2-17-85)

Present address: 2-10-1 Obe, Kawanishi 666-0014, Japan
えて行った（前報挿図参照）。当時の信者たちは, 黄金色で多数の種を持つトウモロコシを豊穣のシン ボルとしてあがめ, 宗教儀式に用いたに違いないと 考えた. そして，コロンブス以前の 12 世紀にイン ドにトウモロコシが存在していたということは一般 見解に矛盾するものになると述べた. ${ }^{4)}$

賛成論5,6) は，ヒンドゥー教，ジャイナ教の寺院 に広範囲に彫刻されているその物体は確かにトウモ ロコシの雌穂であり，それらの寺院は 12-13 世紀に 建立されているから，その時点でトウモロコシはイ ンドでかなり一般化されていたと考えられるとする.

反論7)としては，それらの寺院が建立された 13 世紀にトウモロコシがその地で栽培されていたとい う証拠がないばかりか，インド大陸の他のどの地域 でも当時その栽培はなかった．神像のその装飾物体 をトウモロコシの雌穂とするのは誤りであると結論 する。.またの反論6,8,9) は，それらの彫刻物体はジャ イナ教の図像によっているもので，ジャイナ教の宇 宙観に重要な聖像を，図像的に変形させて表現した ものであるとする。 また，真珠から作られるとされ る空想の果物 muktaphala（真珠のフルーツ）がこ の彫刻のもとではないかとする. ${ }^{6}$

インドに古くから存在していたとすると，その由 来の源は何処であろうか. アラブ商人であろうか. 太平洋横断ルートであろうか. 


\section{3. ヒマラヤ地域}

インドから中国へとつながる北路をみると，ビル マ, チベットに接する北東ヒマラヤ山脈地域が浮か びあがる. $2,10,11)$ それらの地域に生育するトウモロ コシの特異な様相についていくつかの研究があ り, ${ }^{12)}$ 遺伝子解析も始まっている. 各地のもののゲ ノム解析, DNA 比較・鑑定が進めば, ${ }^{13)}$ トウモロ コシ伝播の経路に光が当たることになる，成果が期 待される.

ヒマラヤ北東部のネパール，シッキム，ブー タン, 北ビルマなどの土地に住む人たちは, 古くか らその習慣，伝統，経済の各面でトウモロコシと深 く関わつてきていること, ${ }^{12)}$ またネパールの 14 世 紀の王家の記録にもトウモロコシについての記載が あること ${ }^{14)}$ な゙からも，これら北東ヒマラヤ地域に コロンブス以前にトウモロコシが栽培されていたと する主張を支持するむきが多い. ${ }^{2,15)}$

インド，ヒマラヤ地域にコロンブス以前にトウモ ロコシが入ってきていたとすると，それは太平洋横 断ルートでなければならないといわれる. ${ }^{12)}$ そうで なければ，この種のトウモロコシの移動を示す痕跡 が西からの貿易路沿いに残されていてよいはずであ る。そうした痕跡がみられないことからして，太平 洋諸島, 東南アジアを横断するルートを通ってヒマ ラヤ地方に入ってきたことが示唆される. ${ }^{12,16)}$

\section{4. 中 東}

インドとアフリカの中間の地域，中東にも早くか らトウモロコシがあったことがダルブケルケの記録 に残されている. ${ }^{17)}$ アルフォンゾ・ダルブケルケは 1511 年にマレー半島のマラッカを攻略してポルト ガル領としたことで名をはせた人物である. ${ }^{18)}$

インドへの途上 1508 年の紅海・アデン湾東のソ コトラ島（イエメン）での観察で，トウモロコシが その地の常食であること, マスカット（オマーン） で小麦，大麦，トウモロコシが豊富にあり，また内 陸から大量に小麦, 大麦, トウモロコシ, ナツメヤ シ（果実）が運ばれてきて多数の船に積まれている こと, アラビアの港町ソアールから大量のナッメヤ シとトウモロコシが積み出されていること，また，

ホルムズ王国（中世イスラーム世界で東方貿易の中 心）の大都市オレファサオには沢山のトウモロコシ 畑があること一一な゙が記されている. ${ }^{17)}$ それらに より，アラビア半島を取り巻く地域に少なくとも
16 世紀の当初にトウモロコシが存在していたこと が分かる.

インドへのトウモロコシが西からのアラブ人によ るものであることの証拠は今のところ，ありそうで ない.インドでトウモロコシを makka jouri, makka jola, mukka cholam（いずれもメッカのトウモロ コシ), makkai (メッカの穀物) (サウジアラビア の都市メッカ）ということから，中東由来が示唆さ れる。他方，サンスクリットでトウモロコシを markata というので，それからの mak, maka によ るとし，メッカ由来に反対の解釈もある. ${ }^{12)}$

\section{5. コロンブスの書簡}

トウモロコシ伝播のルートとして，新大陸と大西 洋をはさんで向かい合うアフリカ，そして旧大陸に ついて検討する。

コロンブスは 3 回目の航海（1498-1500）のとき 国王に送った書簡で「(現地人が酒を作る) マイス というのは，マソルカのような穂がある穀果で，私 はこれを彼地に持ち帰りましたし，既にカスティ リヤにも沢山あるものです」と書いたことを前報で 述べた. 119-22) 彼が「既にカスティリヤ（スペイン 中・北部地方，スペインの旧称）にも沢山ある」と 記したことに注目し，それが事実とすれば，いつご ろ，どのようにしてスペインにトウモロコシがもた らされたのかを検討する。 それには，まずアフリカ への接近が必要になる.

\section{6. 西アフリカ}

ポルトガルが国王の力をもって海外に進出するの は，エンリケ親王が 1415 年にアフリカ北端のセウ 夕（ジブラルタルの南対岸）を攻略したことに始ま る. ${ }^{18)} そ し て ~ 1488$ 年にバルトロメウ・ディアシュ (1450?-1500)がアフリカ南端の喜望峰に到達する. この約 70 年間，ポルトガル人，さらにイギリス 人，オランダ人も加わって西アフリカ沿岸各地が探 索される. ${ }^{18)}$ もちろん，エンリケ親王以前の時代に ヨーロッパの航海者たちがアフリカ西岸に達してい たことは想像に難くない。ただ記録，証拠として残 るものがない.

西アフリカのギニア海岸に 1442 年に到達したポ ルトガル人らは，ある種の穀物をそこにみて milho (ミルホ) de Guynee（ギニアの穀物，ギニ

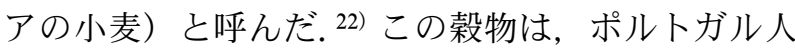
の到来以前に現地でサブッロ zaburro と呼ばれてい 
たのでポルトガル人はそれを milho zaburro と呼ん だ. ${ }^{21,23)}$ このサブッロが 1502 年にギニアからサン トメ島（ギニア湾ガボン沖）に輸出され，そこで栽

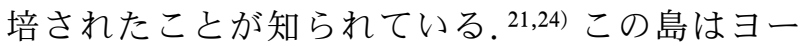
ロッパ向けの奴隷売買の中心地であった。

ギニア海岸など西アフリカ沿岸の地にみられたこ の穀物は, モロコシとの植物学的比較検討, 特に多 雨耐性，短期熟成，穀種の大きさなどの比較検討か らトウモロコシと同定され， ${ }^{22)}$ ポルトガル語でもと もと穀物を指した milho（ミルホ）がトウモロコシ を指すようになった．コロンブス以前に西アフリカ にトウモロコシが存在していたということである.

\section{7. 東アフリカ}

トウモロコシは東アフリカにも早くから存在して いた. バスコ・ダ・ガマ(1469?-1524）は 1498 年, ケニア海岸のモンバサで，またその北のマリンディ の洋上で拿捕船が積んでいた大量のトウモロコシを 入手している. ${ }^{25)}$ ガマの到着時点で既にその地にト ウモロコシが存在していた. また，1505 年にギニ アのものと同様のミルホがタンザニア海岸キルワに 既に沢山あったとされる。 ${ }^{26)}$ また，キルワの城塞で 1506 年に糧食としてトウモロコシが用意されてい た. ${ }^{27)}$ さらに，内陸のソファラ（ボッワナ）では 1506 年の王家の物品購入表にトウモロコシがあ り，住民はトウモロコシのパンを作っているとの報 告がある. ${ }^{27)}$ 以上の数例からでも分かるようにトウ モロコシは東アフリカでも広く知られていた. ${ }^{22)}$

ポルトガル人の到来以前にアフリカで生育してい たトウモロコシの源泉と由来の経路はどのようで あったろうか. ポルトガル人がインド洋に出現する はるか以前に，アラブ商人，インド商人，あるいは その代理人としてのイスラーム化したアフリカ黒人 たちによって東アフリカに移送されてきていたもの であろうとされる. ${ }^{28)}$ また, 西アフリカについても 11 世紀にアラブ人によってもたらされたとする説 もある. ${ }^{21,29,30)}$ もしも，アフリカへの到来がアラブ 人の手によるものとすると，コロンブス以前に大西 洋を横断する接触があったということにならざるを えない. ${ }^{21,31,32)}$

\section{8. イベリア半島}

前述の通りコロンブス自身がトウモロコシは「カ スティリャ（旧スペイン）にも沢山ある」とした. また，アメリカから帰投する船舶についての記録を
残したマルティールは, 1493 年の書簡21,31)で「カ リブ諸島の住民は一種の穀物からたやすくパンを 作っている.それはミラノやアンダルシアの人たち の間に豊かにあるものに似ている」としている。そ こでイベリア半島のトウモロコシについてみること にする.

ポルトガルのある詩人は 1492 年ころ, トウモロ コシについての詩を書いている. ${ }^{23)}$ 詩にでるほどト ウモロコシが 15 世紀末にポルトガルで一般に知ら れていたことになる，そして，その元はアフリカ黒 人から北アフリカのモロッコを経由してきたもので あろうとされている. ${ }^{22)}$ ポルトガルではかなり早い 時期からトウモロコシは milho marroco（モロッコ

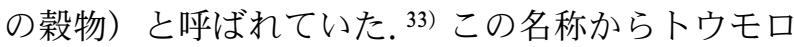
コシは北アフリカのモロッコにあったものが地中海 を北に渡ってイベリア半島に到来したと推測される。

スペインでは 12-13 世紀にアラブ文明が栄え，そ の中心はセヴィリア，コルドバ，グラナダなどであ つた。これらの都市はみな，アラブ人が開拓した農 業の盛んなアンダルシア地方にあった。 そして，モ ロッコに最も近い地域であった。 上記のコロンブス の書簡がいうように，アンダルシア地方にコロンブ ス以前にトウモロコシが存在していた. ${ }^{21,22)}$

そしてイタリアでは，1500 年ころに初めてトウ モロコシが記録されている. ${ }^{34)}$ トウモロコシは 1500 年にはスペイン, イタリア, 南フランスでは広範囲 に栽培されていたとも述べられている. ${ }^{2}$ また，あ る書簡では, ${ }^{35)}$ モザンビックの住民の食料には豆類 や，ロンバルディア地方 (イタリア北部ミラノ地域) で食されているようなトウモロコシもある。 ただ, ロンバルディアのものの方が品質はよいと述べられ ている.

イベリア半島へのトウモロコシの伝来は，ギニア を出発点として，1502 年にサントメ島，そして カーポ・ベルデ諸島（セネガル西海上）から海路を 直接に，またギニアから北のモロッコを経由してき たものとも考えられる。 ${ }^{23)}$ 記録によれば36) 1454 年 にアンダルシアの船隊がセネガル，ガンビアに至つ ており，1475-1480 年の間，アンダルシアの人たち はしばしば西アフリカを往来している.

イベリア半島への伝来の時期については，コロン ブス書簡からしても，さらにさかのぼるであろう. スペインへの 1223-1279 年の輸入品の中にトウモロ 
コシが含まれていたとの報告があるし, ${ }^{37)} 1289$ 年に

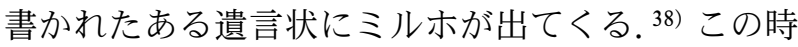
既にポルトガルにトウモロコシがあったことの証拠 となる。

9. 結 論

ポルトガルとともにカスティリヤ，アンダルシ ア，ロンバルディアにもトウモロコシがあったとす る早期の記録と，モロッコ，東西アフリカ沿岸地域 で広範囲な栽培がなされていたという報告から，12 世紀にアフリカに，そして 13 世紀にスペインに導 入されたとみることができる。

\section{0. さらなる論題}

この結論はさらなる疑問を提起する．新大陸から コロンンブス一行によってもたらされたと今までさ れてきたトウモロコシ以外の各種の動・植物につい ても，あるいはより早期の到来があったのではない かという疑問である．そして，さらに大きな論題と して，新大陸と旧大陸の接触がコロンブス以前に既 にあったということにまでさかのぼることになる.

\section{REFERENCES}

1) Uchibayashi M., Yakugaku Zasshi, 126, 27-36 (2006).

2) Paliwal R. L., "El Maiz en los Própios: Mejoramiento y productión - Origen, evolución y diffusion del maiz." www.fao.org /DOCREP/003/X7650S/x7650s03.htm.

3) Johannessen C., Nature, 332, 587 (1988).

4) Johannessen C., Parker A. Z., Econ. Bot., 43, 164-180 (1989).

5) Gupta S., "Plants in Indian Temple Art," B.R. Publishing Corp., Dehli, 1996.

6) McCulloch J. H., Midwest Epigraphic J., 12/ 13, 43-44 (1998-1999).

7) Payak M. M., Sachan J. K. S., Nature, 335 , 774 (1988).

8) Veena T., Prem G., Sigamani N., "Maize-like Structure at Somnathpur Temple of South India," Institute for Oriental Study, Thane, December 2, 2002.

9) Payak M. M., Sachan J. K. S., Econ. Bot., 47, 202 (1993).

10) Laufer B., "The Introduction of Maize into East Asia," Congrès International des Americanistes, XVe Session, 1906.

11) Ho P.-T., Am. Anthropol., 57, 191-201
(1955).

12) Kumar M., Sachan J. K. S., Maize Genetics Corp. Newsl., 67, 98 (1993).

13) Maize Genomics in GOOGLE search, including www.maizegenetics.net/germplasm, and Asian Maize Biotechnology Network.

14) Gopalaraja Vamsavali, chronicle of Nepalese Gopala kings compiled in 14th century AD., given in ref 12. www.spinybabbler.org/art complex/patan.htm, www.nppa-us.org/dabu /vol4no1/treasure.html.

15) Anderson E., Chronica Botanica, 9, 88-92 (1945).

16) Marszewski T., Folio Orient., 19, 127-163 (1978).

17) Dalboquerque A., "The Commentaries of the Great Alfonso Dalboquerque" 1875, English translation by Birch W.d.G., Hakluyt Society, London.

18) Uchibayashi M., "Migi-no-Bunka to Hidarino-Bunka,” Kinokuniya-shoten, Osaka, 1998, pp. 173, 178.

19) Colon Cristobal Don., "A Letter Sent by Colon from Espanora to the King dated October 18, 1498, on His Third Voyage," Japanese translation "Kokai-no- Kiroku" in "Daikoukai-sosho," Vol. 1, Iwanami-shoten, Tokyo, 1965, p. 157.

20) "Life of Christopher Columbus," Chap. X, "The Third Voyage," www.public-domaincontent.com/bools.

21） Jeffreys M. D. W., Anthropolo. J. Can., 3, 211 (1965)

22) Jeffreys M. D. W., "The Anthropology of Food and Food Habits," ed. by Arnott M. L., Mouton Publishing, The Hague, 1975, pp. 2366.

23) Godinho V. M., Rev. Econ., 15, 33-38 (1963).

24) Monod T., Bull.l'I.F.A.N., 22, Series A: 1983 (1960).

25) Ravenstein E. G., "A Journal of the First Voyage of Vasco da Gama 1497-1499," Halkuyt Society, London, 1898.

26) Axelson E., “'Southeast-Africa 1488-1530," Longmann Green, London, 1940.

27) Rego A.da S., Baxton T. W., “'Documents on the Portuguese in Mozam-Bique and Central Africa 1497-1840," Lisbon, English transla- 
tion in 1962 of Years 1497-1516.

28) Pearce F. B., "'Zanzibar, the Island Metropolis of Eastern Africa,' T. Fisher Unwin, London, 1920.

29) Li H.-L., Harv. J. Asiatic Stud., 23, 19601961.

30) Jeffreys M. D. W., Scientia, July-August, 1953.

31) Lunde P., Saudi Aramco World, 43, May/ June, 1992.

32) Gallagher I. J., Dexter W. W., "Contact with Ancient America,'” published by Gallagher I.J., 2004.
33) Ribeiro O., Biblos, 17, 645-663 (1941).

34) Bon M., “'Mais,' Enciclopedia Italiana, Rome, 1924-1932.

35) Theal G. M., "Records of South Eastern Africa," Capetown, Government Printer, 1898.

36) Blake J. W., "European Beginnings in West Africa 1454-1578,' Longmann Green, London, 1937.

37) Marques J. M.da S., "Descobrimentos Portugueses," Instituto de Alta Cultura, Lisbon, 1944.

38) Viterbo St. R. de, “Elucidario,' Ferdinand de Lopes A. J., Lisbon, 1865 (1792). 